\title{
Pengaruh Ukuran Perusahaan, Leverage, dan Likuiditas terhadap Kualitas Laba dengan Profitabilitas sebagai Variabel Moderating
}

\author{
Vita Nurul Azizah' ${ }^{1}$, Asrori2 ${ }^{*}$ \\ Universitas Negeri Semarang \\ vitanuru103@gmail.com, asroriunnes@mail.unnes.ac.id
}

*Penulis korespondensi

Diajukan : 20 Januari 2022

Disetujui : 3 Februari 2022

Dipublikasi : 3 Februari 2022

\begin{abstract}
This research intends to find out the influence of firm size, leverage, and liquidity on earnings quality with profitability as a moderating variable. The property and real estate companies listed on Indonesia Stock Exchange for the period 2017 to 2020 is used as the population in this recearch. This study used a purposive sampling technique with 77 units of analysis obtained. The analytical technique used in this research is Ordinary Least Square (OLS) using the SPSS 25 application. The study shows that firm size have no influence on earnings quality and leverage have no influence on earnings quality, while liquidity has a significant positive influence on earnings quality. Profitability can strengthen the influence of company size on earnings quality. On the other hand, profitability can weaken the influence of leverage on earnings quality but, profitability can not strengthen the influence of liquidity on earnings quality. The conclusions of this research that liquidity has a significant positive influence on earnings quality. Profitability can strengthen the influence of firm size on earnings quality and profitability can weaken the influence of leverage on earnings quality. Suggestions for a new research are expected to add different independent variables which have influence on earnings quality.
\end{abstract}

Keywords: Earnings Quality; Firm Size; Leverage; Liquidity; Profitability

\section{PENDAHULUAN}

Laporan keuangan merupakan media untuk menyampaikan kondisi finansial perusahaan yang mampu mencerminkan kapabilitas manajemen dalam mengelola perusahaan (Wati \& Putra, 2017). Laporan keuangan yang disampaikan secara lengkap oleh perusahaan akan sangat membantu dan bermanfaat untuk pihak-pihak yang memiliki keperluan dengan perusahaan tersebut. Laporan keuangan memiliki berbagai elemen, dimana salah satunya merupakan laba. Laba merupakan salah satu elemen yang bermakna. Laba dapat menilai bagaimana prestasi suatu perusahaan selama satu periode (Fitriani et al., 2020). Laba mampu dijadikan sebagai salah satu pertimbangan pemakai laporan keuangan dalam mengambil suatu kesimpulan. Laba dianggap berkualitas ketika laba tersebut tersaji sinkron sesuai dengan performa keuangan perusahaan yang semestinya dan terhindar dari campur tangan pihak-pihak tertentu (Taruno, 2013). Dengan laba yang berkualitas, memperlihatkan bahwa prestasi perusahaan dalam hal keuangan berada dalam keadaan yang baik.

Laba tidak selalu dapat diandalkan untuk dijadikan sebagai alasan dalam mengambil 
keputusan ekonomi (Khafid \& Mukhibad, 2016). Hal tersebut ditunjukkan dengan terdapatnya perusahaan yang melakukan kecurangan pada laporan keuangannya. Kasus berkenaan dengan tindakan kecurangan dalam penyampaian laporan keuangan terdapat pada PT Hanson Internasional Tbk. PT Hanson Internasional Tbk (MYRX) diduga telah melakukan sesuatu yang bertentangan dengan aturan undang-undang pasar modal. Setelah dilakukan pemeriksaan, Otoritas Jasa Keuangan (OJK) memutuskan bahwa PT Hanson Internasional Tbk benar telah membuat suatu kesalahan sebab tidak menerangkan Perjanjian Pengikatan Jual Beli Kavling Siap Bangun dalam laporan keuangannya. Sementara itu, Direktur Utama dari PT Hanson Internasional Tbk Benny Tjokrosaputro juga ditetapkan melakukan pelanggaran sebab terbukti bersalah melanggar Pasal 107 UUPM dan harus menanggung atas Laporan Keuangan Tahunan (LKT) PT Hanson Internasional Tbk periode 31 Desember 2016 yang terdapat kekeliruan (Sugianto, 2019). Fenomena tersebut menggambarkan bahwa kualitas laba perusahaan masih rendah dikarenakan laporan keuangan yang disajikan telah dimanipulasi sehinga tidak mampu mendeskripsikan keuangan perusahaan dengan benar.

Penelitian terdahulu mengenai kualitas laba memperoleh hasil yang masih beragam, berdasarkan pada riset terdahulu penelitian ini menggunakan 3 variabel independen yang mampu memberikan pengaruh kepada kualitas laba antara lain ukuran perusahaan, leverage, dan likuiditas. Ketiga variabel tersebut sering kali digunakan oleh peneliti sebelumnya dan hasil yang diperoleh masih belum konsisten antara lain, ukuran perusahaan memberikan pengaruh positif terhadap kualitas laba (Zatira et al., 2020), ukuran perusahaan memberikan pengaruh negatif pada kualitas laba (Laoli \& Herawaty, 2019; Riyanti, 2020), ukuran perusahaan tidak memberikan pengaruh pada kualitas laba (Wati \& Putra, 2017; Soly \& Wijaya, 2018; Jannah, 2020; Priyandani, 2020). Leverage memberikan pengaruh positif terhadap kualitas laba (Dewi et al., 2020). Leverage memberikan pengaruh negatif terhadap kualitas laba (Laoli \& Herawaty, 2019; Marpaung, 2019; Febriani et al., 2020), leverage tidak memberikan pengaruh terhadap kualitas laba (Wati \& Putra, 2017; Indriana \& Handayani, 2021; Handoko \& Horison, 2020). Likuiditas memberikan pengaruh positif terhadap kualitas laba (Lestari, 2020; Febriani et al., 2020; Zein et al., 2016), likuiditas memberikan pengaruh negatif pada kualitas laba (Wulansari, 2013; Marpaung, 2019), likuiditas tidak memberikan pengaruh pada kualitas laba ( Soly \& Wijaya, 2018; Listyawan, 2017; Zatira et al., 2020).

Tujuan dilaksanakannya penelitian ini guna melakukan analisis dan mendeskripsikan pengaruh ukuran perusahaan, leverage, dan likuiditas terhadap kualitas laba dan profitabilitas dalam memoderasi pengaruh ukuran perusahaan, leverage, dan likuiditas terhadap kualitas laba. Orisinalitas pada penelitian ini adalah dengan menghadirkan profitabilitas sebagai variabel moderating. Dengan hadirnya profitabilitas diharapkan mampu meningkatkan kualitas laba perusahaan. Penelitian berikut menentukan perusahaan property dan real estate periode tahun 2017-2020 sebagai objek penelitian.

\section{STUDI LITERATUR}

\section{Pengaruh Ukuran Perusahaan terhadap Kualitas Laba}

Ukuran perusahaan ialah ukuran besar kecilnya tingkatan suatu perusahaan. Tingkat besar kecilnya ukuran suatu perusahaan bisa mempengaruhi kapabilitas perusahaan dalam mendapatkan keuntungan. Laba yang besar akan menurunkan minat manajer untuk bertindak curang terhadap laporan keuangan perusahaan, dengan demikian, laba yang dimiliki perusahaan tentu menjadi berkualitas. Hal tersebut selaras dengan teori keagenan tipe I menjelaskan mengenai perselisihan diantara manajer dan pemegang saham (Jensen \& Meckling, 1976). Perusahaan besar tentu lebih mampu mendapatkan laba yang tinggi 
daripada perusahaan dengan tingkatan yang kecil. Hal itu disebabkan karena perusahaan besar mempunyai aset dan modal yang besar yang dapat digunakan untuk kegiatan operasional perusahaan guna memperoleh keuntungan. Penelitian terkait dengan pengaruh ukuran perusahaan pada kualitas laba yang dilaksanakan oleh Zatira et al. (2020), Fitriana \& Islami (2018), dan Putra \& Subowo (2016) memperoleh hasil ukuran perusahaan memberikan pengaruh positif signifikan pada kualitas laba.

\section{H1 : Ukuran perusahaan berpengaruh positif signifikan terhadap kualitas laba.}

\section{Pengaruh Leverage terhadap Kualitas Laba}

Leverage ialah rasio yang dimanfaatkan untuk melihat berapa besaran hutang perusahaan kepada pihak luar untuk memenuhi biaya aset perusahaan. Tingginya leverage yang perusahaan miliki dapat berakibat pada menurunnya kualitas laba perusahaan. Hal tersebut dikarenakan tingginya leverage menunjukkan tingginya hutang perusahaan terhadap pihak eksternal. Hutang yang tinggi menjadikan laporan keuangan perusahaan terlihat tidak menarik, sehingga manajer dapat melakukan kecurangan untuk membuat laporan keuangan terlihat menarik bagi pihak-pihak yang memiliki keperluan dengan perusahaan tersebut . Hal tersebut selaras dengan teori keagenan tipe III yang menjelaskan konflik antara pemegang saham dengan kreditur (Jensen \& Meckling, 1976). Dalam teori tersebut dijelaskan bahwa konflik dapat muncul antara pemegang saham dengan kreditur adalah apabila dana yang diperoleh dari kreditur tidak digunakan dengan semestinya dapat memunculkan risiko yang tinggi baik untuk perusahaan maupun kreditur. Penelitian Laoli \& Herawaty (2019), Marpaung (2019), dan Febriani et al. (2020) memperoleh hasil yaitu leverage memberikan pengaruh negatif signifikan pada kualitas laba.

\section{H2 : Leverage berpengaruh negatif signifikan terhadap kualitas laba}

\section{Pengaruh Likuiditas terhadap Kualitas Laba}

Likuiditas merupakan rasio yang dimanfaatkan guna memperkirakan seberapa mampu perusahaan dalam membiayai hutang jangka pendek yang dimiliki ketika memasuki batas akhir pembayaran (Marpaung, 2019). Teori keagenan tipe III menjelaskan adanya konflik antara pemegang saham dengan kreditur (Jensen \& Meckling, 1976). Tingginya likuiditas suatu perusahaan menggambarkan prestasi keuangan yang baik dalam perusahaan tersebut. Prestasi keuangan yang sudah baik dapat menurunkan niat manajer untuk bertindak curang terhadap laporan keuangan. Dengan demikian, laba perusahaan yang tersaji dalam laporan keuangan menjadi berkualitas. Penelitian Lestari (2020), Febriani et al. (2020), dan Zein et al. (2016) memperoleh hasil yaitu likuiditas memberikan pengaruh positif signifikan pada kualitas laba.

\section{H3 : Likuiditas berpengaruh positif signifikan terhadap kualitas laba.}

\section{Pengaruh Ukuran Perusahaan terhadap Kualitas Laba dengan Profitabilitas sebagai Variabel Moderating}

Ukuran perusahaan ialah skala yang biasanya dimanfaatkan untuk melihat besar kecilnya tingkatan perusahaan. Teori keagenan tipe I dalam penelitian ini menerangkan pengaruh dari ukuran perusahaan pada kualitas laba dengan profitabilitas sebagai variabel moderasi. Teori keagenan tipe I menjelaskan perselisihan yang timbul diantara manajer dan pemegang saham (Jensen \& Meckling, 1976). Perusahaan dengan tingkatan yang besar memiliki kapabilitas yang tinggi dalam memperoleh laba, sehingga mempunyai kualitas laba yang baik. Profitabilitas ialah rasio yang biasanya dipakai dalam memperkirakan kapabilitas perusahaan dalam menerima keuntungan. Tingginya nilai profitabilitas mampu mendeskripsikan bahwa perusahaan mempunyai efektifitas yang bagus dalam mengatur 
keuangan. Ukuran perusahaan mampu memberikan pengaruh pada kualitas laba, hadirnya profitabilitas akan meningkatkan pengaruh dari ukuran perusahaan kepada kualitas laba. Penelitian Zatira et al. (2020) dan Putra \& Subowo (2016) memperoleh hasil bahwasanya ukuran perusahaan memberikan pengaruh positif signifikan pada kualitas laba. Selain itu, penelitian Kurniawan \& Suryaningsih (2019), Ardianti (2018) memperoleh hasil bahwa profitabilitas memberikan pengaruh positif signifikan pada kualitas laba.

H4 : Profitabilitas memperkuat pengaruh positif ukuran perusahaan terhadap kualitas laba.

\section{Pengaruh Leverage terhadap Kualitas Laba dengan Profitabilitas sebagai Variabel Moderating}

Leverage dapat dimanfaatkan untuk melihat berapa besar hutang perusahaan yang digunakan untuk mendanai aset (Febriani et al., 2020). Teori keagenan tipe III digunakan untuk menjelaskan pengaruh dari leverage pada kualitas laba dengan profitabilitas sebagai variabel moderating. Leverage perusahaan dengan nilai tinggi dapat berpengaruh pada menurunnya kualitas laba. Namun, dengan profitabilitas yang tinggi hutang perusahaan yang besar dapat dikelola dengan lebih baik. Hutang perusahaan yang besar, jika diimbangi dengan kemampuan menghasilkan laba yang tinggi, maka hutang yang besar tersebut dapat tertutupi oleh laba perusahaan yang tinggi. Sehingga laporan keuangan perusahaan akan terlihat lebih menarik dan kualitas laba perusahaan akan meningkat. Penelitian Jannah (2020), Laoli \& Herawaty (2019), Marpaung (2019), dan Febriani et al. (2020) memperoleh hasil yaitu leverage memberikan pengaruh negatif signifikan pada kualitas laba. Selain itu, penelitian Kurniawan \& Suryaningsih (2019), Ardianti (2018) memperoleh hasil yaitu profitabilitas memberikan pengaruh positif signifikan pada kualitas laba.

H5 : Profitabilitas memperlemah pengaruh negatif leverage terhadap kualitas laba.

\section{Pengaruh Likuiditas terhadap Kualitas Laba dengan Profitabilitas sebagai Variabel Moderating}

Likuiditas dipakai untuk memperkirakan kapabilitas perusahaan guna menyelesaikan kewajiban jangka pendek yang dimiliki ketika memasuki batas akhir pembayaran. Teori keagenan tipe III digunakan untuk menjelaskan pengaruh dari likuiditas pada kualitas laba dengan profitabilitas sebagai variabel moderating. Likuiditas dapat menurunkan atau meningkatkan kualitas laba perusahaan. Tingginya likuiditas yang dimiliki mampu memperlihatkan bahwa perusahaan mempunyai kinerja keuangan yang bagus. Tingginya profitabilitas menggambarkan kinerja perusahaan yang efektif dalam mengelola keuangan, hal tersebut akan menjadikan kualitas laba yang semakin baik. Likuiditas mampu mempengaruhi kualitas laba, dengan adanya profitabilitas maka, pengaruh likuiditas terhadap kualitas laba akan mengalami peningkatan. Penelitian Lestari (2020), Zein et al. (2016), dan Febriani et al. (2020) didapati hasil yaitu likuiditas memberikan pengaruh positif signifikan pada kualitas laba. Selain itu, penelitian Kurniawan \& Suryaningsih (2019), Ardianti (2018) memperoleh hasil yaitu profitabilitas memberikan pengaruh positif signifikan pada kualitas laba.

H6 : Profitabilitas memperkuat pengaruh positif likuiditas terhadap kualitas laba.

\section{METODE}

Perusahaan pada bidang properti dan real estate yang terdaftar di Bursa Efek Indonesia (BEI) periode tahun 2017 - 2020 dipilih untuk dijadikan sebagai objek penelitian ini. Metode dalam mengambil sampel yang diterapkan ialah metode purposive sampling dimana didapati sebanyak 37 perusahaan dengan 148 unit analisis. Setelah dilakukan uji 
statistik, ditemukan adanya data outlier sebanyak 71 unit analisis. Dengan demikian sampel akhir yang diperoleh adalah sebanyak 77 unit analisis. Tahap penentuan sampel tersaji pada tabel berikut:

Tabel 1. Penentuan Sampel Penelitian

\begin{tabular}{|c|c|c|c|}
\hline No & Kriteria & $\begin{array}{l}\text { Tidak } \\
\text { Memenuhi } \\
\text { Kriteria }\end{array}$ & Total \\
\hline 1. & $\begin{array}{l}\text { Perusahaan bidang properti dan real estate yang } \\
\text { terdaftar di Bursa Efek Indonesia (BEI) tahun } \\
2020 \text {. }\end{array}$ & & 79 \\
\hline 2. & $\begin{array}{l}\text { Perusahaan bidang properti dan real estate yang } \\
\text { terdaftar di Bursa Efek Indonesia (BEI) pada } \\
\text { tahun } 2017 \text { hinga } 2020 \text {. }\end{array}$ & & 79 \\
\hline 3. & $\begin{array}{l}\text { Perusahaan bidang properti dan real estate yang } \\
\text { telah menerbitkan laporan tahunan (annual } \\
\text { report) pada tahun } 2017 \text { hingga } 2020 \text { secara } \\
\text { konsisten. }\end{array}$ & (29) & 50 \\
\hline 4. & $\begin{array}{l}\text { Perusahaan bidang properti dan real estate yang } \\
\text { memberikan informasi secara lengkap mengenai } \\
\text { data yang diperlukan untuk melakukan } \\
\text { pengujian pada penelitian ini. }\end{array}$ & (13) & 37 \\
\hline & Perusahaan sampel penelitian & & 37 \\
\hline & Total unit analisis (2017-2020) & & 148 \\
\hline & Data outlier & (71) & 77 \\
\hline & Total akhir unit analisis & & 77 \\
\hline
\end{tabular}

Sumber: Olahan data sekunder, 2021

Berikut merupakan ringkasan dari variabel penelitian ini:

Tabel 2. Definisi Operasional Variabel

\begin{tabular}{|c|c|c|c|c|}
\hline No & $\begin{array}{l}\text { Variabel } \\
\text { Penelitian }\end{array}$ & Deskripsi & Pengukuran & Skala \\
\hline 1. & Kualitas Laba & $\begin{array}{lr}\text { Kualitas laba } & \text { adalah } \\
\text { laba yang } & \text { dapat } \\
\text { menggambarkan } & \\
\text { kondisi } & \text { keuangan } \\
\text { perusahaan } & \text { yang } \\
\text { sebenarnya. } & \end{array}$ & $\begin{array}{l}Q E \\
=\frac{\text { Arus kas operasi }}{\text { Laba bersih }} \\
\text { (Septiyani et al., 2017) }\end{array}$ & Rasio \\
\hline 2. & $\begin{array}{l}\text { Ukuran } \\
\text { Perusahaan }\end{array}$ & $\begin{array}{l}\text { Ukuran perusahaan } \\
\text { adalah tingkatan sebuah } \\
\text { perusahaan yang } \\
\text { mampu diamati melalui } \\
\text { besaran aset yang } \\
\text { dimiliki perusahaan. }\end{array}$ & $\begin{array}{l}\text { Size } \\
=\text { Ln. total asset } \\
\text { (Laoli \& Herawaty, } \\
\text { 2019) }\end{array}$ & Rasio \\
\hline
\end{tabular}




\begin{tabular}{|c|c|c|c|c|}
\hline 3. & Leverage & $\begin{array}{l}\text { Leverage adalah rasio } \\
\text { yang dipakai untuk } \\
\text { melihat besaran hutang } \\
\text { perusahaan untuk } \\
\text { menangani biaya aset } \\
\text { perusahaan. }\end{array}$ & $\begin{array}{l}\text { DER }=\frac{\text { Total hutang }}{\text { Total ekuitas }} \\
\text { (Marpaung, 2019) }\end{array}$ & Rasio \\
\hline 4. & Likuiditas & $\begin{array}{l}\text { Likuiditas adalah rasio } \\
\text { yang dipakai untuk } \\
\text { memperkirakan } \\
\text { kapabilitas perusahaan } \\
\text { dalam menyelesaikan } \\
\text { hutang jangka pendek } \\
\text { yang dimiliki. }\end{array}$ & $\begin{array}{l}\text { CR } \\
=\frac{\text { Aset lancar }}{\text { Kewajiban lancar }} \\
\text { (Soly \& Wijaya, 2018) }\end{array}$ & Rasio \\
\hline 5. & Profitabilitas & $\begin{array}{l}\text { Profitabilitas adalah } \\
\text { rasio yang dipakai untuk } \\
\text { memperkirakan } \\
\text { kapabilitas perusahaan } \\
\text { dalam mendapatkan } \\
\text { keuntungan. }\end{array}$ & $\begin{array}{l}\text { ROE }=\frac{\text { Laba bersih }}{\text { Total ekuitas }} \\
(\mathrm{F} . \quad \text { Dewi \& } \\
\text { Fachrurrozie, 2021) }\end{array}$ & Rasio \\
\hline
\end{tabular}

Sumber: Olahan data sekunder, 2021

\section{Teknik Analisis Data}

Teknik analisis yang diterapkan yaitu teknik analisis statistik deskriptif dan statistik inferensial.

\section{Analisis Statistik Deskriptif}

Analisis ini diterapkan guna mengetahui informasi seperti nilai rata-rata (mean), nilai minimum, nilai maksimum, sum, kurtosis, range, skewness (kemencengan distribusi), dan standar deviasi pada tiap-tiap variabel.

\section{Analisis Statistik Inferensial}

Teknik ini dipakai untuk melakukan pengujian pada hipotesis penelitian. Dalam penelitian berikut teknik analisis inferensial yang diterapkan ialah statistik parametrik.

\section{Uji Asumsi Klasik}

\section{Uji Normalitas}

Pengujian ini diterapkan guna memperoleh informasi berkenaan dengan distribusi data dalam penelitian, memiliki distribusi normal atau tidak. Apabila didapat nilai signifikansi (Sig.) $\geq 0,05$ maka mampu dikemukakan bahwa penelitian mempunyai penyebaran data secara normal

\section{Uji Multikolinearitas}

Pengujian ini dimaksudkan guna memperoleh informasi apakah terdapat korelasi signifikan yang terjadi di antara beberapa variabel yang dipakai dalam penelitian (Wahyudin, 2015). Jika didapati nilai VIF $\leq 10$ dengan nilai tolerance $\geq 0,10$, maka mampu dinyatakan bahwa tidak adanya tanda-tanda multikolinearitas dalam data penelitian.

\section{Uji Autokorelasi}

Pengujian ini dimaksudkan untuk melihat adakah hubungan dalam variabel yang diteliti. Tidak terdapat autokorelasi positif maupun negatif apabila nilai $\mathrm{du}<\mathrm{d}<4$-du.

\section{Uji Heteroskedastisitas}

Pengujian ini dimaksudkan guna mengetahui terdapat atau tidak perbedaan pada varians dari residual yang diteliti. Apabila nilai signifikansi pada uji Glejser $\geq 0,05$ maka mamput diputuskan bahwa data tidak mengalami heteroskedastisitas. 
Owner: Riset \& Jurnal Akuntansi

e-ISSN : 2548-9224 |p-ISSN : 2548-7507

Volume 6 Nomor 1, Januari 2022

DOI : https://doi.org/10.33395/owner.v6i1.712

\section{Uji Hipotesis}

Pengujian hipotesis menggunakan ordinary least square dan analisis regresi moderasi dengan uji interaksi menggunakan software IBM SPSS 25. Persamaan regresi yang diterapkan pada penelitian ini yaitu:

Persamaan I :

$\mathrm{QE}=\alpha+\beta 1 \mathrm{SIZE}+\beta 2 \mathrm{DER}+\beta 3 \mathrm{CR}+\mathrm{e}$

Persamaan II :

$\mathrm{QE}=\alpha+\beta 1 \mathrm{SIZE}+\beta 2 \mathrm{DER}+\beta 3 \mathrm{CR}+\beta 4|\mathrm{SIZE} * \mathrm{ROE}|+\beta 5|\mathrm{DER} * \mathrm{ROE}|+\beta 6|\mathrm{CR} * \mathrm{ROE}|+\mathrm{e}$ (Ghozali, 2018)

Keterangan :

$\mathrm{QE} \quad=$ Kualitas Laba

SIZE = Ukuran Perusahaan

DER = Leverage

$\mathrm{CR} \quad=$ Likuiditas

ROE = Profitabilitas

$\alpha \quad=$ Konstanta

$\beta 1-6=$ Koefisien regresi

e $\quad=$ Standar error

\section{Uji Statistik t}

Pengujian ini dimaksudkan guna mengetahui pengaruh variabel independen terhadap variabel dependen secara individual. Apabila didapat nilai signifikansi $\leq 0,05$ maka mampu diputuskan bahwa hipotesis diterima artinya variabel independen memberikan pengaruh pada variabel dependen, begitu pula sebaliknya.

\section{HASIL}

Hasil pengujian analisis statistik deskriptif ditampilkan dalam tabel berikut:

Tabel 3. Hasil Pengujian Statistik Deskriptif

\begin{tabular}{|l|r|r|r|r|r|}
\hline & N & Minimum & Maximum & \multicolumn{1}{c|}{ Mean } & \multicolumn{1}{c|}{$\begin{array}{c}\text { Std. } \\
\text { Deviation }\end{array}$} \\
\hline X1 & 77 & 25,8371 & 31,6398 & 29,190538 & 1,4056247 \\
\hline X2 & 77 &, 0005 & 1,8316 &, 669114 &, 4734048 \\
\hline X3 & 77 &, 0012 & 5,7028 & 2,225704 & 1,2979394 \\
\hline Z & 77 &,- 1135 &, 2056 &, 052004 &, 0753371 \\
\hline Y & 77 & $-1,3269$ & 2,2019 &, 503991 &, 7106124 \\
\hline Valid N (listwise) & 77 & & & & \\
\hline
\end{tabular}

Sumber: Olahan data sekunder, 2021

Tabel 4. Hasil Pengujian Normalitas

\begin{tabular}{|c|c|c|}
\hline & & Unstandardized Residual \\
\hline $\mathrm{N}$ & & $\begin{array}{ll}77 \\
\end{array}$ \\
\hline Normal Parameters ${ }^{\mathrm{a}, \mathrm{b}}$ & Mean & ,0000000 \\
\hline & Std. Deviation & ,63859603 \\
\hline Most Extreme Differences & Absolute &, 042 \\
\hline & Positive &, 042 \\
\hline
\end{tabular}


Owner: Riset \& Jurnal Akuntansi

e-ISSN : 2548-9224 |p-ISSN : 2548-7507

Volume 6 Nomor 1, Januari 2022

DOI : https://doi.org/10.33395/owner.v6i1.712

\begin{tabular}{|l|l|r|}
\hline & Negative &,- 036 \\
\hline Test Statistic & &, 042 \\
\hline Asymp. Sig. (2-tailed) & &, $200^{\text {c,d }}$ \\
\hline
\end{tabular}

Sumber: Olahan data sekunder, 2021

Dalam uji normalitas didapati nilai signifikansi senilai 0,200, nilai yang diperoleh lebih besar daripada 0,05 dengan demikian, bisa diartikan bahwasanya data telah memiliki distribusi yang normal.

Tabel 5. Hasil Pengujian Multikolinearitas

\begin{tabular}{|l|r|r|}
\hline & \multicolumn{2}{|c|}{ Collinearity Statistics } \\
\hline Model & Tolerance & VIF \\
\hline SIZE &, 804 & 1,243 \\
\hline DER &, 788 & 1,269 \\
\hline CR &, 863 & 1,159 \\
\hline ROE &, 874 & 1,144 \\
\hline
\end{tabular}

Sumber: Olahan data sekunder, 2021

Dalam uji multikolinearitas didapati bahwasanya keseluruhan variabel dalam penelitian didapati angka tolerance $>0,10$ dan nilai variance inflation factor (VIF) $<10$, dengan demikian bisa diputuskan bahwa model tidal mengalami multikolinearitas.

Tabel 6. Hasil Pengujian Autokorelasi

\begin{tabular}{|l|c|r|r|r|c|}
\hline Model & R & R Square & $\begin{array}{c}\text { Adjusted R } \\
\text { Square }\end{array}$ & $\begin{array}{c}\text { Std. Error of the } \\
\text { Estimate }\end{array}$ & $\begin{array}{c}\text { Durbin- } \\
\text { Watson }\end{array}$ \\
\hline 1 &, $503^{\mathrm{a}}$ &, 253 &, 189 & .63989 & 2,121 \\
\hline
\end{tabular}

Sumber: Olahan data sekunder, 2021

Dalam uji autokorelasi nilai durbin watson yang dihasilkan adalah senilai 2,121 sementara itu, nilai du adalah senilai 1,7117. Hasil yang didapat menunjukkan nilai d=2,121 lebih besar dibandingkan nilai du=1,7117 dan lebih kecil dibandingkan dengan nilai 4-du=2,2883 dengan demikian, bisa diputuskan bahwa model tidak mengalami autokorelasi.

Tabel 7. Hasil Pengujian Heteroskedastisitas

\begin{tabular}{|l|l|r|r|r|r|r|}
\hline $\begin{array}{l}\text { Mod } \\
\text { el }\end{array}$ & & $\begin{array}{c}\text { Unstand } \\
\text { ardized } \\
\text { B }\end{array}$ & $\begin{array}{c}\text { Coefficient } \\
\text { s Std. } \\
\text { Error }\end{array}$ & $\begin{array}{c}\text { Standardized } \\
\text { Coefficients } \\
\text { Beta }\end{array}$ & \multicolumn{1}{|c|}{ t } & \multicolumn{1}{|c|}{ Sig. } \\
\hline 1 & $\begin{array}{l}(\text { Constant } \\
\text { ( }\end{array}$ &, 122 & 1,009 & &, 121 &, 904 \\
\hline & SIZE &, 008 &, 036 &, 028 &, 225 &, 823 \\
\hline & DER &, 201 &, 107 &, 241 & 1,882 &, 064 \\
\hline & CR &, 024 &, 037 &, 079 &, 646 &, 520 \\
\hline & ROE &,- 894 &, 638 &,- 170 & $-1,400$ &, 166 \\
\hline
\end{tabular}

Sumber: Olahan data sekunder, 2021

Dalam pengujian heteroskedastisitas memperlihatkan bahwa keempat variabel didapati nilai signifikansi di atas nilai 0,05 dengan demikian, bisa diputuskan bahwa data tidak mengalami heteroskedastisitas. 
Owner: Riset \& Jurnal Akuntansi

e-ISSN : 2548-9224 |p-ISSN : 2548-7507

Volume 6 Nomor 1, Januari 2022

DOI : https://doi.org/10.33395/owner.v6i1.712

Tabel 8. Hasil Pengujian Regresi I

\begin{tabular}{|l|l|r|r|r|r|r|}
\hline $\begin{array}{l}\text { Mod } \\
\text { el }\end{array}$ & $\begin{array}{c}\text { Unstand } \\
\text { ardized } \\
\text { B }\end{array}$ & $\begin{array}{c}\text { Coefficient } \\
\text { s Std. } \\
\text { Error }\end{array}$ & $\begin{array}{c}\text { Standardized } \\
\text { Coefficients } \\
\text { Beta }\end{array}$ & t & \multicolumn{1}{|c|}{ Sig. } \\
\hline 1 & $\begin{array}{l}\text { (Constan } \\
\text { t) }\end{array}$ & $-2,308$ & 1,649 & & $-1,400$ &, 166 \\
\hline & SIZE &, 083 &, 058 &, 165 & 1,439 &, 154 \\
\hline & DER &,- 037 &, 183 &,- 025 &,- 201 &, 841 \\
\hline & CR &, 180 &, 064 &, 329 & 2,828 &, 006 \\
\hline
\end{tabular}

Sumber: Olahan data sekunder, 2021

Menurut pengujian regresi yang tersaji dalam tabel 8 , persamaan dari regresi yang dihasilkan yaitu:

$\mathrm{Y}=-2,308+0,083 \mathrm{SIZE}-0,037 \mathrm{DER}-0,180 \mathrm{CR}+\mathrm{e}$

Tabel 9. Hasil Pengujian Regresi II

\begin{tabular}{|l|l|r|r|r|r|r|}
\hline Model & & $\begin{array}{c}\text { Unstandardized } \\
\text { B }\end{array}$ & $\begin{array}{c}\text { Coefficients } \\
\text { Std. Error }\end{array}$ & $\begin{array}{c}\text { Standardized } \\
\text { Coefficients } \\
\text { Beta }\end{array}$ & t & Sig. \\
\hline 1 & (Constant) &,- 623 & 1,701 & &,- 366 &, 715 \\
\hline & SIZE &, 018 &, 060 &, 036 &, 300 &, 765 \\
\hline & DER &, 169 &, 228 &, 113 &, 740 &, 462 \\
\hline & CR &, 182 &, 067 &, 332 & 2,702 &, 009 \\
\hline & SIZE_ROE &, 339 &, 115 & 1,053 & 2,939 &, 004 \\
\hline & DER_ROE & $-6,265$ & 2,939 &,- 572 & - &, 037 \\
& & $-1,628$ &, 903 &,- 442 & -131 &, 076 \\
\hline & CR_ROE & & & & 1,802 & \\
\hline
\end{tabular}

Sumber: Olahan data sekunder, 2021

Menurut pengujian regresi yang tersaji dalam tabel 9, persamaan dari regresi yang dihasilkan yaitu:

$$
\begin{aligned}
& \mathrm{Y}=-0,623+0,018 \mathrm{SIZE}+0,169 \mathrm{DER}+0,182 \mathrm{CR}+0,311\left|\mathrm{SIZE} \_\mathrm{ROE}\right|-6,372\left|\mathrm{DER} \_\mathrm{ROE}\right| \\
& \mathbf{1 , 0 1 2}\left|\mathrm{CR} \_\mathrm{ROE}\right|+\mathrm{e}
\end{aligned}
$$

Tabel 10. Ringkasan Hasil Pengujian Hipotesis

\begin{tabular}{|c|l|c|c|c|}
\hline No & \multicolumn{1}{|c|}{ Hipotesis } & Koefisien & Signifikasi & Hasil \\
\hline 1. & $\begin{array}{l}\text { Ukuran perusahaan berpengaruh positif } \\
\text { signifikan terhadap kualitas laba (H2) }\end{array}$ & 0,083 & 0,154 & Ditolak \\
\hline 2. & $\begin{array}{l}\text { Leverage berpengaruh negatif signifikan } \\
\text { terhadap kualitas laba (H3) }\end{array}$ & $-0,037$ & 0,841 & Ditolak \\
\hline 3. & $\begin{array}{l}\text { Likuiditas berpengaruh positif } \\
\text { signifikan terhadap kualitas laba (H4) }\end{array}$ & 0,180 & 0,006 & Diterima \\
\hline 4. & $\begin{array}{l}\text { Profitabilitas memperkuat pengaruh } \\
\text { positif ukuran perusahaan terhadap } \\
\text { kualitas laba (H5) }\end{array}$ & 0,339 & 0,004 & Diterima \\
\hline
\end{tabular}




\begin{tabular}{|l|l|c|c|c|}
\hline 5. & $\begin{array}{l}\text { Profitabilitas memperlemah pengaruh } \\
\text { negatif leverage terhadap kualitas laba } \\
\text { (H6) }\end{array}$ & $-6,265$ & 0,037 & Diterima \\
\hline 6. & $\begin{array}{l}\text { Profitabilitas memperkuat pengaruh } \\
\text { positif likuiditas terhadap kualitas laba } \\
\text { (H7) }\end{array}$ & $-1,628$ & 0,076 & Ditolak \\
\hline
\end{tabular}

Sumber: Olahan data sekunder, 2021

Tabel 11. Hasil Pengujian Koefisien Determinasi (Adjusted $\mathrm{R}^{2}$ )

\begin{tabular}{|l|r|r|r|r|}
\hline Model & R & R Square & \multicolumn{1}{|c|}{$\begin{array}{c}\text { Adjusted R } \\
\text { Square }\end{array}$} & \multicolumn{1}{c|}{$\begin{array}{c}\text { Std. Error of the } \\
\text { Estimate }\end{array}$} \\
\hline 1 &, 503 &, 253 &, 189 &, 63989 \\
\hline
\end{tabular}

Sumber: Olahan data sekunder, 2021

Nilai adjusted R square yang didapat adalah senilai 0,189. Nilai tersebut menandakan bahwa variabel dalam penelitian mampu menerangkan variabel dependen sebesar 18,9\%, melainkan kekurangannya yaitu 81,4\% diterangkan oleh variabel lain yang tidak digunakan.

\section{PEMBAHASAN}

\section{Pengaruh Ukuran Perusahaan terhadap Kualitas Laba}

Menurut pengujian yang telah dilakukan ditemukan adanya pengaruh dari ukuran perusahaan pada kualitas laba, sehingga hipotesis pertama ditolak. Hasil tersebut bertentangan dengan teori keagenan tipe I. Ukuran perusahaan tidak memberikan pengaruh pada kualitas laba suatu perusahaan, salah satu penyebabnya yaitu karena perusahaan besar mempunyai risiko usaha yang besar pula serta biaya-biaya operasional yang besar. Besarnya ukuran perusahaan juga tidak selalu mempunyai laba yang tinggi dan berkualitas begitupun sebaliknya. Hal tersebut dapat disebabkan oleh tindakan manajemen yang tidak mampu mengelola keuangan sesuai harapan. Hasil tersebut mendukung penelitian dari Wati \& Putra (2017), Soly \& Wijaya (2018), Jannah (2020), Priyandani (2013) yang menyampaikan bahwasanya ukuran perusahaan tidak memberikan pengaruh pada kualitas laba.

\section{Pengaruh Leverage terhadap Kualitas Laba}

Menurut pengujian yang telah dilakukan ditemukan tidak adanya pengaruh dari leverage pada kualitas laba, sehingga hipotesis kedua ditolak. Hasil tersebut tidak selaras dengan teori keagenan tipe III. Leverage tidak mempengaruhi tinggi rendahnya kualitas laba dapat ditimbulkan oleh tingkat hutang yang perusahaan miliki dalam keadaan yang optimal. Perusahaan dengan keuangan yang baik tidak akan melakukan manipulasi laporan keuangan. Selain itu, tingginya tingkat leverage juga tidak selalu memunculkan niat manajemen untuk bertindak curang dalam melaporkan laba, apabila risiko yang diterima perusahaan kecil. Hasil tersebut mendukung penelitian dari Riyanti (2020), Wati \& Putra (2017) yang menyampaikan bahwasanya leverage tidak memberikan pengaruh pada kualitas laba.

\section{Pengaruh Likuiditas terhadap Kualitas Laba}

Menurut pengujian yang telah dilakukan membuktikan bahwasanya likuiditas memberikan pengaruh positif signifikan pada kualitas laba, sehingga hipotesis ketiga, diterima. Hasil tersebut tidak selaras dengan teori keagenan tipe III. Likuiditas yang meninggi menandakan bahwa perusahaan telah efektif dalam mengelola keuangan. Sebuah perusahaan tentu akan menyajikan informasi keuangannya dengan luas, ketika performa keuangan perusahaan tersebut dalam kondisi yang bagus. Dengan demikian, kecil 
kemungkinan perusahaan yang mempunyai kinerja keuangan yang efektif untuk melakukan manipulasi laporan keuangan. Hasil yang didapat mendukung penelitian yang dilaksanakan oleh Zein et al. (2016), Lestari (2020), serta Febriani et al. (2020) yang menyampaikan bahwa likuiditas memberikan pengaruh positif pada kualitas laba.

\section{Pengaruh Ukuran Perusahaan terhadap Kualitas Laba dengan Profitabilitas sebagai Variabel Moderating}

Pengujian yang telah dilakukan memberikan bukti bahwa profitabilitas memperkuat pengaruh ukuran perusahaan pada kualitas laba, sehingga hipotesis keempat, diterima. Hasil tersebut tidak selaras dengan teori keagenan tipe I. Perusahaan yang mempunyai profitabilitas tinggi cenderung akan menyampaikan informasi keuangan perusahaan lebih banyak dan sesuai dengan kondisi yang semestinya. Perusahaan berukuran besar dengan profitabilitas tinggi akan memiliki kemungkinan kecil untuk bertindak kecurangan dalam menyajikan laporan keuangan, karena laporan keuangan yang dimiliki sudah terlihat menarik. Menurut literatur yang diketahui oleh peneliti, belum ada penelitian terdahulu yang menggunakan profitabilitas untuk memoderasi pengaruh ukuran perusahaan pada kualitas laba. Namun, pengaruh ukuran perusahaan pada kualitas laba didukung penelitian dari Zatira et al. (2020) dan Putra \& Subowo (2016) yang menyampaikan ukuran perusahaan memberikan pengaruh positif signifikan pada kualitas laba. Sementara itu, pengaruh profitabilitas pada kualitas laba mendukung penelitian Kurniawan \& Suryaningsih (2019), Ardianti (2018) yang memperoleh hasil bahwa profitabilitas memberikan pengaruh positif signifikan pada kualitas laba.

\section{Pengaruh Leverage terhadap Kualitas Laba dengan Profitabilitas sebagai Variabel Moderating}

Pengujian yang telah dilakukan memberikan bukti bahwasanya profitabilitas mampu melemahkan pengaruh leverage pada kualitas laba, sehingga hipotesis kelima diterima. Hasil yang didapat selaras dengan teori keagenan tipe III. Profitabilitas memiliki kemampuan memperlemah pengaruh negatif leverage pada kualitas laba. Profitabilitas dengan nilai yang meninggi menandakan bahwa sebuah perusahaan mempunyai kapabilitas yang tinggi dalam memperoleh keuntungan. Tingginya profitabilitas juga mampu untuk menutupi hutang perusahaan yang besar, sehingga laporan keuangan perusahaan akan terlihat lebih menarik. Menurut literatur yang diketahui oleh peneliti, belum ada penelitian terdahulu yang menggunakan profitabilitas untuk memoderasi pengaruh leverage pada kualitas laba. Namun, berkenaan dengan pengaruh leverage pada kualitas laba selaras dengan penelitian Jannah (2020), Marpaung (2019), Febriani et al. (2020), dan Laoli \& Herawaty (2019) yang menyampaikan bahwa leverage memberikan pengaruh negatif signifikan terhadap kualitas laba. Sementara pengaruh profitabilitas pada kualitas laba selaras dengan penelitian Kurniawan \& Suryaningsih (2019), Ardianti (2018)yang menyampaikan bahwa profitabilitas memberikan pengaruh positif signifikan pada kualitas laba.

\section{Pengaruh Likuiditas terhadap Kualitas Laba dengan Profitabilitas sebagai Variabel Moderating}

Pengujian yang telah dilakukan memberikan bukti bahwasanya profitabilitas tidak dapat memperkuat pengaruh likuiditas pada kualitas laba, sehingga hipotesis keenam ditolak. Hasil yang didapat tidak selaras dengan teori keagenan tipe III. Profitabilitas tidak terbukti dapat memperkuat pengaruh likuiditas pada kualitas laba. Tingkat profitabilitas mampu memperlihatkan kapasitas keuntungan yang didapatkan perusahaan, namun 
kenaikan maupun penurunan profitabilitas tidak dapat menunjukkan baik atau tidaknya kualitas laba. Hal tersebut disebabkan karena laba yang besar dapat diperoleh perusahaan akibat melakukan tindakan kecurangan dalam melaporkan laba, sehingga kualitas laba perusahaan berubah menjadi rendah. Menurut literatur yang diketahui oleh peneliti, belum ada penelitian terdahulu yang menggunakan profitabilitas untuk memoderasi pengaruh likuiditas pada kualitas laba namun, pengaruh likuiditas pada kualitas laba didukung oleh penelitian Zein et al. (2016), Lestari (2020), serta Febriani et al. (2020) yang menyampaikan bahwa likuiditas memberikan pengaruh positif pada kualitas laba sementara itu, pengaruh profitabilitas pada kualitas laba didukung oleh penelitian Ginting (2017), Lestari (2020), dan Jannah (2020) yang menyampaikan hasil bahwa profitabilitas tidak memberikan pengaruh pada kualitas laba.

\section{KESIMPULAN}

Berdasarkan pembahasan hasil penelitian yang telah dipaparkan, dapat disimpulkan bahwa ukuran perusahaan tidak berpengaruh positif signifikan terhadap kualitas laba. Leverage tidak berpengaruh negatif signifikan terhadap kualitas laba. Likuiditas berpengaruh positif signifikan terhadap kualitas laba. Profitabilitas memperkuat pengaruh positif ukuran perusahaan terhadap kualitas laba. Profitabilitas memperlemah pengaruh negatif leverage terhadap kualitas laba dan profitabilitas tidak memperkuat pengaruh positif likuiditas terhadap kualitas laba.

\section{REFERENSI}

Ardianti, R. (2018). Pengaruh Alokasi Pajak Antar Periode, Persistensi Laba, Profitabilitas, Dan Likuiditas Terhadap Kualitas Laba (Studi Empiris Pada Perusahaan Manufaktur yang Terdaftar di BEI Tahun 2012-2016). Jurnal Akuntansi, 6(1), 85-102. https://doi.org/10.24964/ja.v6i1.593

Dewi, F., \& Fachrurrozie. (2021). Pengaruh Ukuran Perusahaan, Profitabilitas, Leverage, Kepemilikan Manajerial, dan Kepemilikan Institusional terhadap Kualitas Laba. Beaj, 1(1), 1-13. http://beaj.unnes.ac.id

Dewi, I. G. A. S. D., Endiana, I. D. M., \& Arizona, P. E. (2020). Pengaruh Laverage, Invesment Opportunity Set (IOS), dan Mekanisme Good Corporate Covernance terhadap Kualitas Laba Pada Perusahaan Manufaktur di Bursa Efek Indonesia. Jurnal Kharisma, 2(1), 125-136.

Febriani, K., Saraswati, D., Merawati, L. K., \& Munidewi, I. A. B. (2020). Pengaruh Likuiditas, Leverage dan Good Corporate. Jurnal Ekonomi Dan Pariwisata, 15(2), 79-89.

Fitriana, V. E., \& Islami, I. N. (2018). The Relationship Of Firm Size, CEO Ability, Tax Aggressiveness, To Earnings Quality. International Journal of Economics, Commerce and Management, United Kingdom, 6(2), 495-508.

Fitriani, A. I., Febrianto, H. G., \& Utomo, E. N. (2020). Faktor-Faktor yang Mempengaruhi Kualitas Laba pada Perusahaan LQ45 yang Terdaftar di BEI. Universitas Muhammadiyah Jakarta, 1-9. http://jurnal.umj.ac.id/index.php/semnaslit

Ghozali, I. (2018). Aplikasi Analisis Multivariate dengan Program IBM SPSS 25. Badan Penerbit Universitas Diponegoro.

Ginting, S. (2017). Pengaruh Profitabilitas, Likuiditas dan Ukuran Perusahaan Terhadap Kualitas Laba pada Perusahaan Manufaktur yang Terdaftar di Bursa Efek Indonesia. Wira Ekonomi Mikroskil, 7(2), 227-236.

Handoko, B. L., \& Horison, R. (2020). The Effect of Firm Size, Audit Committee, Leverage and Institutional Ownership on Earnings Quality. International Journal of 


\section{Recent Technology and Engineering, 8(5), 4510-4516.} https://doi.org/10.35940/ijrte.e6817.018520

Indriana, V., \& Handayani, N. (2021). Pengaruh Leverage, Investment Opportunity Set (IOS) dan Profitabilitas terhadap Kualitas Laba. Jurnal Ilmu Dan Riset Akuntansi, 10, $1-18$.

Jannah, M. (2020). Pengaruh Profitabilitas Likuiditas Leverage, Ukuran Perusahaan dan Perubahan Laba terhadap kualitas laba. 1, 1-15.

Jensen, M., \& Meckling, W. (1976). Theory of The Firm: Managerial Behavior, Agency Costs and Ownership Structure. Journal of Financial Economics 3, 72(10), 305-360. https://doi.org/10.1177/0018726718812602

Khafid, M., \& Mukhibad, H. (2016). Apakah Kualitas Laba Berbasis Akuntansi Berkontribusi Terhadap Market Outcomes? Jurnal Keuangan Dan Perbankan, 20(1), 42-49. https://doi.org/10.26905/jkdp.v20i1.147

Kurniawan, C., \& Suryaningsih, R. (2019). Pengaruh Konservatisme Akuntansi, Debt To Total Assets Ratio, Likuiditas, Profitabilitas, dan Ukuran Perusahaan Terhadap Kualitas Laba. Equity, 21(2), 163. https://doi.org/10.34209/equ.v21i2.642

Laoli, A. N., \& Herawaty, V. (2019). Pengaruh Profitabilitas, Growth, Leverage, Operating Cycle dan Prudence Terhadap Kualitas Laba dengan Firm Size Sebagai Variabel Moderasi. Prosiding Seminar Nasional Cendekiawan, 2000, 2. https://doi.org/10.25105/semnas.v0i0.5828

Lestari, S. (2020). Pengaruh Profitabilitas, Pertumbuhan Laba, Leverage Dan Likuiditas Terhadap Kualitas Laba dengan Ukuran Perusahaan sebagai Variabel Moderating. Universitas Negeri Semarang. UNNES.

Listyawan, B. (2017). Pengaruh Struktur Modal, Likuditas, Ukuran Perusahaan, Pertumbuhan Laba, dan Profitabilitas Terhadap Kualitas Laba (Studi Empiris Pada Perusahan Manufaktur yang Terdaftar di Bursa Efek Indonesia Periode 2012-2015). Jurnal Akuntansi Universitas Muhammadiyah Surakarta, 87(1,2), 1-14.

Marpaung, E. I. (2019). Pengaruh Leverage, Likuiditas dan Ukuran Perusahaan Sebagai Variabel Moderasi Terhadap Kualitas Laba. Journal of Accounting, Finance, Taxation, and Auditing (JAFTA), 1(1), 1-14. https://doi.org/10.28932/jafta.v1i1.1524

Priyandani, A. (2020). Pengaruh Struktur Modal, Ukuran Perusahaan dan Likuiditas terhadap Kualitas Laba dengan Konservatisme Akuntansi sebagai Variabel Moderasi. In Universitas Negeri Semarang (Vol. 53, Issue 9).

Putra, N. Y., \& Subowo. (2016). The Effect of Accounting Conservatism, Investment Opportunity Set, Leverage, and Company Size on Earnings Quality. Accounting Analysis Journal, 5(4), 299-306. https://doi.org/10.15294/aaj.v5i4.10691

Riyanti, I. (2020). Pengaruh Profitabilitas, Leverage, Ukuran Perusahaan, dan Pertumbuhan Laba terhadap Kualitas Laba dengan Persistensi Laba sebagai Variabel Moderating. In Universitas Negeri Semarang.

Septiyani, G., Rasyid, E., \& Tobing, E. G. (2017). Faktor-Faktor Yang Mempengaruhi Kualitas Laba Pada Perusahaan Industri Dasar dan Kimia Yang Terdaftar Di Bursa Efek Indonesia Periode 2012-2015. Fundamental Management Journal, 2(1), 70-79.

Soly, N., \& Wijaya, N. (2018). Faktor-Faktor Yang Mempengaruhi Kualitas Laba pada

Perusahaan Manufaktur. Jurnal Bisnis Dan Akuntansi, 19(1), 47-55. https://doi.org/10.34208/jba.v19i1.64

Sugianto, D. (2019). Terbukti Manipulasi Laporan Keuangan, Benny Tjokro Didenda Rp $5 \quad M$. Www.Finance.Detik.Com. https://finance.detik.com/bursa-dan-valas/d4658394/terbukti-manipulasi-laporan-keuangan-benny-tjokro-didenda-rp-5-m

Taruno, S. A. (2013).Pengaruh Corporate Governance terhadap Kualitas Laba: Manajemen 
Laba Sebagai Variabel Intervening. Accounting Analysis Journal, 2(3), 323-329.

Wahyudin, A. (2015). Metodologi Penelitian Penelitian Bisnis \& Pendidikan. Unnes Press.

Wati, G., \& Putra, I. W. (2017). Pengaruh Ukuran Perusahaan, Leverage, dan Good Corporate Governance Pada Kualitas Laba. E-Jurnal Akuntansi, 19(1), 137-167.

Wulansari, Y. (2013). Pengaruh Investment Opportunity, Likuiditas, dan Laverage Terhadap Kualitas Laba Perusahaan Manufaktur yang Terdaftar DI BEI. Jurnal Akuntansi, 26(4), 1-37.

Zatira, D. S., Hilda, N., Erdawati, L. (2020). Prosiding Konferensi Nasional Ekonomi Manajemen dan Akuntansi (KNEMA) Journal Homepage. Jurnal UMJ, Konferensi, 1-14. https://jurnal.umj.ac.id/index.php/KNEMA

Zein, K., Surya, R., \& Silfi, A. (2016). Pengaruh Pertumbuhan Laba, Struktur Modal, Likuditas dan Komisaris Independen Terhadap Kualitas Laba dengan Komisaris Independen Dimoderasi Oleh Kompetensi Komisaris Independen (Studi pada Perusahaan Manufaktur yang terdaftar pada Bursa Efek Indonesia pe. Jurnal Online Mahasiswa Fakultas Ekonomi Universitas Riau, 3(1), 980-992. 